\title{
Chromosome 16p11.2 deletions: another piece in the genetic puzzle of childhood obesity
}

\author{
Laura Perrone, Pierluigi Marzuillo, Anna Grandone and Emanuele Miraglia del Giudice*
}

\begin{abstract}
Ipercaloric diet and reduced physical activity have driven the rise in the prevalence of childhood obesity over a relatively short time interval. Family and twin studies have led to the conclusion that the strong predicitve value of parental body mass index (BMI) mainly stems from genetic rather than environmental factors. Whereas the common polygenic obesity arises when an individual genetic make-up is susceptible to an environment that promotes energy consumption over energy expenditure, monogenic obesity, on the contrary, is the obesity associated with a single gene mutation, which is sufficient by itself to cause weight gain in a food abundant context. Genes involved in the leptin-melanocortin pathway are often mutated in these cases. The cumulative prevalence of monogenic obesity among children with severe obesity is about $5 \%$.

Recently, deletions in the region p11.2 of the chromosome 16 encompassing the gene $\mathrm{SH} 2 \mathrm{~B} 1$, which is involved in the leptin and insulin signaling, have been reported in about $0.5 \%$ of children with severe early-onset obesity. These patients show extreme hyperphagia, severe insulin resistance and, in some cases, mild developmental delay.
\end{abstract}

\section{Introduction}

Childhood obesity appears particularly alarming considering the strong association with increased rates of premature death from endogenous causes observed in a cohort of American children followed for more than 20 years [1].

Ipercaloric diet and reduced physical activity have driven the rise in the prevalence of adult and childhood obesity over a relatively short time interval $[2,3]$. The genetic contribution to body weight has been established through family studies investigating parent-offspring relationships and the study of twins and adopted children. These studies have led to the conclusion that the strong predictive value of parental body mass index (BMI) mainly stems from genetic rather than environmental factors. Twin studies, in comparison to family and adoption studies, have revealed that between 40 and 70\% of the BMI variance within a population can be expalined by genetic effects [4-6].

The molecular approach has revealed several candidate genes for the human obesity and has cleary positioned interactions between genetic make-up and enviroment to

* Correspondence: emanuele.miraglia@unina2.it

${ }^{1}$ Department of Pediatrics "F. Fede" Seconda Università degli Studi di Napoli, Via Luigi De Crecchio 2,80138, Napoli, Italy

Full list of author information is available at the end of the article understand the mechanisms involved in fat-mass expansion [7-9].

Considering the genetic point of view obesity is classified in i) monogenic obesity, that is the obesity associated with a single gene mutation; in these cases single gene variants are sufficient by themselves to cause obesity in food abundant societies; patients with monogenic obesity usually show extremely severe phenotypes characterized by childhood obesity onset, often associated with additional behavioral, developmental or endocrine disorders $[10,11]$; ii) syndromic obesity (this includes some Mendelian disorders in wich patients are clinically obese and are additionally distinguished by mental retardation, dysmorfic features, and organ-specific developmental abnormalities) [12] and iii) polygenic obesity; this very common kind of obesity, which concerns the great majority of obese children, arises when an individual genetic make-up is susceptible to an environment that promotes energy consumption over energy expenditure [13].

The study of extreme human obesity caused by single gene defects has provided a glimpse into the long-term regulation of body weight and has shown that the hypothalamic leptin-melanocortin system is critical for energy balance in humans, because disruption of this pathway causes the most severe obesity phenotypes. Briefly, leptin is an adipocyte-derived satiety hormone that signals the

(c) 2010 Perrone et al; licensee BioMed Central Ltd. This is an Open Access article distributed under the terms of the Creative Commons B. Wed Central Attribution License (http://creativecommons.org/licenses/by/2.0), which permits unrestricted use, distribution, and reproduction in any medium, provided the original work is properly cited. 
size of the fat depot interacting with the leptin receptor in the nucleus arcuatus of the hypothalamus. The signal is then forwarded via the alpha-melanocyte stimulating hormone to the melanocortin- 4 receptor allowing appetite suppression and increasing energy expenditure. Mutations in genes involved in this pathway accounts for not more than $5 \%$ of all childhood severe obesity cases (Table 1). In fact, whereas mutations of the leptin (LEP) and proopiomelanocortin $(\mathrm{POMC})$ genes are rare $[14,15]$, both mutations of the melanocortin-4 receptor (MC4R) and of the leptin receptor (LEPR) genes have been reported in about $2-3 \%$ of the children with severe obesity $[16,17]$.

\section{Discussion}

In the last years it has been discovered that genetic differences among people can derive from lost or duplicated segments of chromosomes, called copy number variants (CNVs) [18].

A recent work of Farooqi et al analyzed the genomes of 300 obese children for missing or duplicated chromosome segments [19]. All patients had severe obesity defined as a BMI standard deviation score $>3$, obesity onset before 10 years of age and 143 of them also showed developmental delay. Mutations in LEPR, POMC and MC4R genes were previously excluded by direct nucleotide sequencing. A number of CNVs were more common in the obese children than in a group of normalweight controls $(\mathrm{p}=0.0005)$. The commonest CNV found in these patients was identified in five unrelated children harbouring overlapping deletions on chromosome 16p11.2. In three patients this deletion co-segregated with severe obesity, whereas in the remaining two children the deletion occurred de novo and was particularly large, extending through a region previously associated with autism and mental retardation. Interestingly, both patients had mild developmental delay in addition to severe obesity. Pooling the data obtained in a replication cohort of 1062 Caucasian obese patients with those from the original discovery set, the prevalence of chromosome $16 \mathrm{p} 11.2$ deletions associated to severe early-onset obesity alone (i.e.; without developmental delay) was $0.41 \%$. The same kind of deletion was found in only 2 out of 7366 controls $(\mathrm{p}<0.001)$.

All these deletions encompass several genes, some of them involved in neurological disorders or immunity, but include also the gene SH2B1, which is known to be involved in insulin signaling [20]. Mice lacking this gene become extremely fat and develop hyperphagia, insulin resistance, hepatic steatosis and type 2 diabetes [21,22]. Furthermore, SH2B1 is a key intermediary in leptin signaling, promoting the activation of the leptin signaling pathway downstream of JAK2 [23-25]. Additionally, neuron-specific overexpression of SH2B1 in obese mice, protects against diet-induced leptin and insulin resistance [26].

Accordingly, the phenotype of the children with SH2B1-containing deletions is characterized by extreme hyperphagia and fasting insulin levels disproportionately elevated compared to age and obesity-matched controls [19].

Similar data (i.e.; deletions on chromosome 16p11.2) have been reported in a population prevalently made up by adults with severe obesity, further demonstrating the potential importance in common diseases of rare variants with strong effects [27].

\section{Conclusions}

The progress in the knowledge of the human genome and the discovery of new genetic disorders allowed to catego-

Table 1: Childhood early-onset monogenic obesity due to the involvement of the genes belonging to the leptin-melanocortin pathway.

\begin{tabular}{lcccc}
\hline GENE & CHROMOSOME & INHERITANCE & PREVALENCE & PHENOTYPIC FEATURES \\
\hline LEP & $7 \mathrm{q} 31.1$ & Recessive & Rare & $\begin{array}{c}\text { Severe obesity, Hyperphagia, Hypogonadotropic hypogonadism, } \\
\text { Central hypothyroidism. }\end{array}$
\end{tabular}

\begin{tabular}{|c|c|c|c|c|}
\hline LEPR & $1 p 31$ & Recessive & $1.5 \%$ & $\begin{array}{c}\text { Severe obesity, Hyperphagia, Hypogonadotropic hypogonadism and } \\
\text { central hypothyroidism (in some cases) }\end{array}$ \\
\hline
\end{tabular}

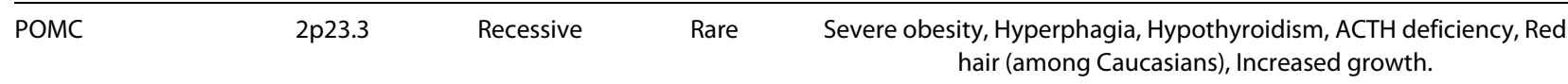

\begin{tabular}{llrl}
\hline MC4R $18 \mathrm{q} 22$ & Dominant & $2.5 \%$ & $\begin{array}{r}\text { Severe obesity, Hyperphagia, Excess fat and lean mass, Severe } \\
\text { hyperinsulinaemia, Increased growth. }\end{array}$
\end{tabular}

\begin{tabular}{lcccc}
\hline $\begin{array}{l}\text { Deletions } \\
\text { involving SH2B1 }\end{array}$ & $16 \mathrm{p} 11.2$ & $\begin{array}{c}\text { Dominant or } \\
\text { de novo }\end{array}$ & $0.5 \%$ & $\begin{array}{c}\text { Severe obesity, Hyperphagia and severe insulin resistance } \\
\text { disproportionate for the degree of obesity, Mild developmental delay } \\
\text { (in some cases). }\end{array}$
\end{tabular}


rize the human obesity as a medical condition rather than simply a moral failing.

The clinical evaluation of the severely obese children is becoming increasingly sophisticated. There are a lot of genes that can be implicated in the obesity and obese patients in the world are too much to perform molecular study for everyone. It would be useful to identify particular phenotypes and clinical features that can help to recognize the subjects to investigate with genetic screening. The presence of severe obesity in a young child ( $<5 \mathrm{yr}$ old) associated to extreme hyperphagia, severe insulin resistance disproportionate for the degree of obesity and a positive family history of early-onset obesity may support a genetic analysis. The cumulative prevalence of monogenic obesity among children with severe obesity is not more than 5\% (Table 1). Nevertheless, considering the great proportion of obese children worldwide [28], the possibility exists that in countries such as Italy, many thousands of children might be carriers of this kind of mutations.

In conclusion, the work of Farooqi et al reports the first rare CNVs associated with obesity, suggests a role for SH2BI in human energy homeostasis and glucose metabolism and adds another important contribution to the understanding of the complicated puzzle of the genetic basis of early onset obesity.

\section{Competing interests}

The authors declare that they have no competing interests.

\section{Authors' contributions}

LP, PM and AG were involved in drafting the manuscript, EMdG revised it critically. All authors read and approved the final manuscript.

\section{Author Details}

Department of Pediatrics "F. Fede" Seconda Università degli Studi di Napoli, Via Luigi De Crecchio 2, 80138, Napoli, Italy

Received: 30 April 2010 Accepted: 11 June 2010

Published: 11 June 2010

\section{References}

1. Franks PW, Hanson RL, Knowler WC, Sievers ML, Bennett PH, Looker HC: Childhood obesity, other cardiovascular risk factors, and premature death. N Engl J Med 2010, 362:485-493.

2. Kopelman PG: Obesity as a medical problem. Nature 2000, 404:635-643.

3. Ogden CL, Flegal KM, Carroll MD, Johnson CL: Prevalence and trends in overweight among US children and adolescents, 1999-2000. JAMA 2002, 288:1728-1732.

4. Maes HH, Neale MC, Eaves $\mathrm{L}$ : Genetic and environmental factors in relative body weight and human adiposity. Behav Genet 1997, 27:325-351.

5. Stunkard AJ, Sørensen TI: Obesity and socioeconomic status, a complex relation. N Eng/ J Med 1993, 329:1036-1037.

6. Hebebrand J, Wulftange H, Goerg T, Ziegler A, Hinney A, Barth N, Mayer H, Remschmidt $\mathrm{H}$ : Epidemic obesity: are genetic factors involved via increased rates of assortative mating? Int J Obes Relat Metab Disord 2000, 24:345-253.

7. Barsh GS, Farooqi IS, O'Rahilly S: Genetics of body-weight regulation. Nature 2000, 404:644-651.

8. Comuzzie AG: The emerging pattern of the genetic contribution to human obesity. Best Pract Res Clin Endocrinol Metab 2002, 16:611-621.
9. Hunter DJ: Gene-environment interactions in human diseases. Nat Rev Genet 2005, 6:287-298.

10. Rankinen T, Zuberi A, Chagnon YC, Weisnagel SJ, Argyropoulos G, Walts B, Pérusse L, Bouchard C: The human obesity gene map: the 2005 update. Obesity 2006, 14:529-644.

11. Bell CG, Walley AJ, Froguel P: The genetics of human obesity. Nat Rev Genet 2005, 6:221-234

12. Farooqi IS: Monogenic human obesity. Front Horm Res 2008, 36:1-11.

13. Hetherington MM, Cecil JE: Gene-environment interactions in obesity. Forum Nutr 2010, 63:195-203.

14. Mutch DM, Clément K: Unraveling the genetics of human obesity. PLoS Genet 2006, 2:e188.

15. O'Rahilly S, Farooqi IS: Genetics of obesity. Philos Trans R Soc Lond B Biol Sci 2006, 361:1095-1105.

16. Farooqi IS, Wangensteen T, Collins S, Kimber W, Matarese G, Keogh JM, Lank E, Bottomley B, Lopez-Fernandez J, Ferraz-Amaro I, Dattani MT, Ercan O, Myhre AG, Retterstol L, Stanhope R, Edge JA, McKenzie S, Lessan N, Ghodsi M, De Rosa V, Perna F, Fontana S, Barroso I, Undlien DE, O'Rahilly S: Clinical and molecular genetic spectrum of congenital deficiency of the leptin receptor. N Engl J Med 2007, 356:237-247.

17. Santoro N, Cirillo G, Xiang Z, Tanas R, Greggio N, Morino G, lughetti L, Vottero A, Salvatoni A, Di Pietro M, Balsamo A, Crinò A, Grandone A, Haskell-Luevano C, Perrone L, Miraglia del Giudice E: Prevalence of pathogenetic MC4R mutations in Italian children with early onset obesity, tall stature and familial history of obesity. BMCMed Genet 2009, 12:10-25.

18. Sha BY, Yang TL, Zhao LJ, Chen XD, Guo Y, Chen Y, Pan F, Zhang ZX, Dong $\mathrm{SS}, \mathrm{Xu} X \mathrm{XH}$, Deng HW: Genome-wide association study suggested copy number variation may be associated with body mass index in the Chinese population. J Hum Genet 2009, 54:199-202.

19. Bochukova EG, Huang N, Keogh J, Henning E, Purmann C, Blaszczyk K, Saeed S, Hamilton-Shield J, Clayton-Smith J, O'Rahilly S, Hurles ME, Farooqi IS: Large, rare chromosomal deletions associated with severe earlyonset obesity. Nature 2010, 463:666-670.

20. Ren D, Zhou Y, Morris D, Li M, Li Z, Rui L: Neuronal SH2B1 is essential for controlling energy and glucose homeostasis. J Clin Invest 2007, 117:397-406.

21. Li M, Ren D, Iseki M, Takaki S, Rui L: Differential role of SH2-B and APS in regulating energy and glucose homeostasis. Endocrinology 2006, 147:2163-2170.

22. Ren D, Li M, Duan C, Rui L: Identification of SH2-B as a key regulator of leptin sensitivity, energy balance, and body weight in mice. Cell Metab 2005, 2:95-104.

23. Li Z, Zhou Y, Carter-Su C, Myers MG Jr, Rui L: SH2B1 enhances leptin signaling by both Janus kinase 2 Tyr813 phosphorylation-dependent and -independent mechanisms. Mol Endocrinol 2007, 21:2270-2281.

24. Nishi M, Werner ED, Oh BC, Frantz JD, Dhe-Paganon S, Hansen L, Lee J, Shoelson SE: Kinase activation through dimerization by human SH2-B. Mol Cell Biol 2005, 25:2607-2621.

25. Rui L, Carter-Su C: Identification of SH2-bbeta as a potent cytoplasmic activator of the tyrosine kinase Janus kinase 2. Proc Natl Acad Sci USA 1999, 96:7172-7177

26. Ren D, Zhou Y, Morris D, Li M, Li Z, Rui L: Neuronal SH2B1 is essential for controlling energy and glucose homeostasis. J Clin Invest 2007, 117:397-406.

27. Walters RG, Jacquemont S, Valsesia A, de Smith AJ, Martinet D, Andersson J, et al: A new highly penetrant form of obesity due to deletions on chromosome 16p11.2. Nature 2010, 463:671-675.

28. Wojcicki JM, Heyman MB: Let's Move: childhood obesity prevention from pregnancy and infancy onward. N Engl J Med 2010, 362:1457-1459.

doi: 10.1186/1824-7288-36-43

Cite this article as: Perrone et al., Chromosome 16p11.2 deletions: another piece in the genetic puzzle of childhood obesity Italian Journal of Pediatrics 2010, 36:43 